\title{
Ethics education in Romanian economics faculties, members of AFER
}

\author{
Andreia MANEA \\ Bucharest University of Economic Studies, Bucharest, Romania \\ maneaandreial4@stud.ase.ro \\ Răzvan HOINARU \\ Queen Mary University of London, London, UK \\ r.hoinaru@qmul.ac.uk \\ Cătălin-Paul PĂCURARU-IONESCU \\ Bucharest University of Economic Studies, Bucharest, Romania \\ paul@pacuraru.com
}

\begin{abstract}
This paper aims to provide a high-level overview of whether and how ethics is taught in Romanian accounting and business faculties, members of the Association of Economics Faculties of Romania (AFER), at Bachelor or Masters' level (accounting, audit or business administration programs).

While there are numerous research papers on how ethics is taught in general and some national surveys in other countries, this is the first analysis of its kind in Romania and it can be helpful for faculties to compare themselves to what their counterparts are doing to teach this important topic for professionals in accounting and business. We analysed the publicly available (detailed and most recent) curricula of 60 programs (22 bachelor and 38 masters) from 14 faculties in 8 Romanian cities. We found out whether ethics is included as a self-standing course or ingrained in the curricula (based on our own hypothesis which we then verified) and whether it is predominantly an optional or a mandatory discipline. We found that, with a few exceptions, the majority of programs analyzed approached ethics (academic or professional) and that the Ethics self-standing courses (or the courses where ethics is included as a secondary subject) have a relatively high importance (judged from the number of credits allocated to them). There are many other variables to analyze in order to make the research more relevant for professors that would want to update their ethics curricula. One would be for instance to analyze whether currently ethics is taught more towards senior years or at the beginning of students' education.
\end{abstract}

Key words: ethics, education, courses, deontology, governance.

\section{Introduction}

In a world of uncertainties and rapid change (financial crisis, pandemics, automation) people are rightly wondering what remains a constant and what is the value added of the accountancy profession. The latter's sense of morals and professional judgement should act as a steady compass through this storm. And this has happened throughout centuries.

From the very establishment of the accountancy profession, at its roots, Luca Pacioli engrained ethics mentions based on the Catholic Social Teaching in his Summa (Coate and Mitschow, 2018). Ever since that very beginning, ethics has been intertwined with the accountancy profession and it has taken more or less a central stage depending on economic context, crises and general attitudes towards accountants. 
Many have tried to answer some overarching questions regarding ethics education in accounting:

- Can it be taught? (Kerr and Smith,1995; Kaufmann, 2018);

- How can it be taught? (Davidson, 2011);

- How can we improve ethics education? (Chelariu et al., 2014, table).

In this paper we have tried to use knowledge from a couple of research papers approaching how accountants and business professionals have been, are and could be taught ethics in order to make as comprehensive as possible a research on whether and how Ethics is approached in courses offered by Romanian BA, accounting and audit programs from faculties members of AFER (Association of Romanian Economical Faculties) and on the relative importance of these courses.

We wanted to provide a landscape of how Ethics is included in Romanian economical faculties' curricula and the most relevant group of faculties for this research seemed to be members of the Association of Romanian Economics Faculties comprising 60 members throughout Romania. AFER is the only association of its kind in Romania, hence it makes sense to use information on its members when asking the question how Ethics is taught in Economics faculties.

All these faculties' curricula are regulated by standards issued by ARACIS (Romanian Agency to Ensure Quality in Higher Education). ARACIS mentions in their Specific standards on external assesment of academic quality of Masters and BSc Programs (issued on 27.04.2017) that for BSc's in Business Administration as well as for BSc's in Accounting it is mandatory to include in their curricula a ,humanist" discipline and business ethics is quoted as an example (togehter with sociology, psichology, politology, philosophy, geography, economic history). So there is no formal requirement for ethics to be included at BSc level. In the same document there is no mention about Ethics under any form needing to be included in a Master's programs.

Hence, this research will hopefully give a first glimpse into how Ethics is included in courses of these Romanian Economics faculties, members of AFER, and its relative importance. The primary benefit of this research could be that it will allow interested professors to map their Ethics course or generic curricula against the results of this analysis.

\section{Literature review}

We started this research by performing a high-level overview of the most important aspects and variables influencing ethics education in accounting, its tools, their impact and how these could be improved. The main focus of our research was on other experiences of educating ethics so that we can start asking the right questions as to how Ethics is covered in certain Economics faculties in Romania, which, as far as we know, is the first research of this kind.

We ignored papers which did not have accounting ethics education in focus and which were not reputable.

We found that ethics has been intertwined with the accountancy profession since its very beggining when Luca Pacioli engrained Catholic Social Teaching in his Summa (Coate and Mitschow, 2018) however specifically ethics education for business did not catch up until early 20th century and it seems that it still raises controversies as to who, what should teach and what its impact is and also it is not as present as it should be in either academia (Miller and Shawver, 2018) or professional bodies (Fleming, 1996; Spalding, 2019).

Throughout the years, interest in researching ethics education increased (Nguyen and Dellaportas, 2020), however the quality and prevalence of business ethics education itself did not increase (Fisher et al. 2007 in Leung et al., 2008; Miller and Becker 2014). 


\section{History and current adoption of ethics education}

Teaching ethics for business dates back to early in the twentieth century (Lovell, 2004 in Leung et al., 2008) and this coincides with the formal establishment of codes of professional conduct for certified or chartered accountants (Jakubowski, 2002) while the first article on accounting ethics education was published in 1972 (Nguyen, 2020). This was also the only article on the topic published in that decade.

Despite since increasing interest in research, there appeared to be a downward trend in business ethics courses in the US in spite of having even legislative reforms reinforcing the need for additional ethics education (Fisher et al., 2007 quoted in Leung et al., 2008; Sinoi, 2021). So much so that in 2011 for instance in a study of accounting programs in 97 US universities, Miller and Becker (2014) found that most of their curricula did not even cover fundamental ethics topics (definitions and terminology for instance).

Representatives of the academia agreed that ethics should be more present in both accounting courses as a self-standing course and integrated in the curricula in their universities as they recognized the benefits if students had formal ethical training but also because probably, they did not believe that students were getting enough post-graduation ethics education. This seems to indicate that although professional bodies have put ethics more at the forefront in their public discourse as well as in their curricula, members of the academia believe that their actions are not enough to give accounting professionals an ethics compass and feel, consequently, more responsible themselves (based on own analysis of the correlations in Table 5 of Miller and Shawver, 2018).

\section{Instruments for teaching ethics (interventions)}

Making sure accountants take ethical decisions can happen through regulation or through education. However, this paper does not approach regulations although they also have an important place in research literature since the first Codes of Ethics for accountants appeared, more than 100 years ago (Jakubowski, 2002).

Miller and Shawver (2018) discovered that the research had had an important gap on how undergraduate accounting programs in the UK were covering ethics, but the authors did not look further into the exact tools used by educators to teach ethics. There is fortunately further research to approach that and we have looked into it in order to be able to extract any such instrument from our analysis of study plans in AFER faculties.

While researching ethics teaching tools, we found the following:

- Case-studies (Thorne et al., 1999 quoted by Leung et al., 2008);

- Ethics textbooks (having the disadvantage that most are too theoretical and with much of the learning examples directed at issues faced by upper level managers and CEOs) (Mathison, 1988 quoted by Leung et al., 2008);

- Lectures (Davidson, 2011);

- Applied ethics workshops (Kaufmann, 2018);

- Homework (Davidson, 2011);

- Reflective learning (personal journal, work logs) (Limijaya, 2019);

- Sharing by guest speaker (Limijaya, 2019);

- Literature and other forms of narrative material (plays, short stories and film) (Young and Annisette, 2009);

- Learning by experience (Huber and Mafi, 2013 quoted by Chelariu et al., 2014);

- Students becoming content creators (Kaciuba, 2012 quoted by Chelariu et al., 2014). 
Having researched some of the tools currently used to teach ethics helped us enhance our vocabulary regarding ethics education so that we knew what to look for in the annual study plans which we analyzed.

Also, by analyzing papers on the effectiveness of accounting ethics education and how we can improve it helped us decide which data to gather from our analysis of study plans. For instance, we decided to also collect the year faculties were teaching the Ethics course inspired by Fiolleau and Kaplan 2017 who had researched ethical sensitivity of accounting students compared to practicing industry accountants (so different stages of seniority). Also, we found through research that another determinant of the effectiveness of teaching ethics in accounting is the moment and timeline of the intervention. That is, whether the intervention is punctual (a self-standing course Miller et al., 2014) or spread-out in the accounting curriculum (Shawver, 2017). How many times it is repeated and by whom are also important and related questions hence we decided to also include courses which only engrain ethics as a point of discussion not as the main subject itself.

This high-level literature review of what we found to be the main facets in accounting ethics education is just the top of the iceberg of extensive existing research but it helped us enhance our knowledge in the area and start building what we believe can be a useful analysis of the Romanian ethics education landscape.

\section{Methodology}

We analyzed all study plans of programs from Economics faculties, members of AFER, addressing accounting, audit and Business Administration at both Bachelor's and Master's level, full-time education.

We eliminated, from the very start of our research, programs that addressed marketing, tourism, general economics, international relations or any other economic topics. Also, if a faculty was offering the same program in another city, we did not include the program twice, however if we found that a program was offered by the same faculty in several languages we included all its versions. We came up with a total of 66 programs at Bachelor's and Master's level. We downloaded the most recent study plans from the faculties' websites (so publicly available information) and found that 6 of these Master's degrees did not have full available information online regarding their curricula. Hence, we ended up with 60 programs (22 Bachelor's and 38 Master's) which were included in our analysis. These came from 14 Faculties in 8 cities of Romania (Bucuresti, Brasov, Cluj, Craiova, Galati, Iasi, Targu Jiu, Timisoara).

We performed a quantitative analysis determining first how many courses had "ethics", "deontology" and "doctrine" in their title and we determined that those were courses were ethics was taught as a self-standing subject (we called them Self-Standing Courses or SSCs).

Then, based on our previous literature review, we hypothesized that other subject matters like Corporate Governance, Corporate Governance and Internal Control Systems, Creative Accounting, Economic Doctrines, History of World Economy and Sustainable Development and Economic Progress might include Ethics to quite an extended degree and we took those courses into account as well, and called them IOCs (or Ethics Ingrained in Other Course).

In order to test our hypothesis whether these other selected subjects we assumed might approach (or engrain) ethics really do tackle it, we have downloaded the detailed subject outlines for the aforementioned six disciplines from six random faculties.

Then we searched the documents for the following key words: ethics, code, fraud, responsibility, doctrine and morals. We found that all six subject outlines besides History of World Economy contained at least one of the searched words. Hence, we decided to keep only five of the 
subjects for our analysis as approaching ethics formally. We eliminated History of World Economy and History of Economics from our initial findings (two instances at the same Faculty, in two BSc programs) but kept for instance History of economic doctrine and History and corporate doctrine. This still left us with 60 programs to analyze as in none of the initially found programs we had found History of (World) Economics as only subject that approaches ethics.

In total, we found Ethics to be present in 123 courses of which only 24 optional. Thirtythree of them were Ethics and Academic Integrity so the approach towards the subject of Ethics was from the point of view of research and developing the academic dissertation thesis and not from the professionals' point of view. However, we decided to include this course as well as we deemed that any encounter by future accounting professionals with Ethics is relevant for their future development (i.e., we considered that Ethics and Academic integrity as a self standing subject has the same weight as Doctrine and Deontology in the Accountancy Profession as self standing subject. Hence, in our analysis we did not make a further split between academic ethics being taught and professional ethics being taught).

For these 123 courses we input into a Microsoft Excel file a couple of variables: how many credits they carried, in what year and semester of studies they were taught and whether they were mandatory or optional within the program. We then used the data to draw some initial conclusions as to the proportion of courses included in the analyzed programs as well as to what is the perceived importance of the Ethics courses, based on the number of awarded credits or whether they were mandatory or not.

\section{Data limitations}

We did not find publicly available study plans for all AFER members' full-time programs in audit, accounting or Business Administration. Two did not include the number of credits awarded for each discipline, one missed the curricula for the second year of studies and three lacked study plans altogether. These six programs, all at Master's level, were eliminated from our analysis.

Another issue we found was that some documents were not searchable so we needed to read all study plans for the key words, an activity made even more difficult by the fact that there is no agreed template or universally used acronyms for the study plans.

Data was transcribed by hand into a Microsoft Excel file and hence it is prone to some error.

\section{Results and discussions}

From the study plans of the 60 programs analyzed we found that only 5 (3 BSc and 2 Master's) did not include Ethics at all either as SSC or IOC and they were all Business Administration programs (in conjunction with Entrepreneurship and International Economics in two instances).

Of the 55 remaining, 2 programs at BSc level had Ethics taught only in one SSC which was also optional (both were Business Administration) and 1 program at Master's level was in the same situation (Management of Financial Accounting Information Systems). Three Master's programs have only IOCs, however none is optional.

In total, we found 123 courses in which Ethics is a Self-standing subject or in which Ethics is approached, 99 of them being mandatory. Thirty-seven of these courses ( 8 in BSc and 29 in Masters) were determined as potentially including ethics in their curricula based on authors' hypothesis. This hypothesis was tested by analyzing the detailed subject outlines of six of the subjects which we initially supposed included ethics as well. The testing left us with only five such subjects which are covered in the 37 courses, 26 of them being mandatory. 
Given that $92 \%$ of analyzed programs include Ethics as either professional or academic subject and that $80 \%$ of these courses are mandatory under the circumstances in which the regulator (ARACIS) is not formally requesting them, we can safely draw the conclusion that the subject of Ethics is given a high importance in Economics Faculties in Romania. Three out of five programs not including Ethics were at BSc level.

Further analyzing the split of how Ethics is included in researched courses we noticed that almost $50 \%$ of BSc programs included two or more courses tackling ethics while at Master's level $71 \%$ of programs had two or more courses approaching the subject.

From the total Masters programs analyzed, close to 50\% included three or more courses in which ethics was tackled and $20 \%$ included Ethics in four courses, with an absolute champion, a Master degree in financial Audit and Management which included 3 SSCs and 1 IOC and all were mandatory.

Table 1. Number of courses approaching ethics in programs on accounting audit and BA (from faculties members of AFER)

\begin{tabular}{|l|l|l|l|}
\hline $\begin{array}{c}\text { Ethics as Self standing course (SSC) } \\
\text { or Ethics ingrained in other course (IOC) }\end{array}$ & $\begin{array}{c}\text { Total number of courses } \\
\text { in which Ethics } \\
\text { is included }\end{array}$ & $\begin{array}{c}\text { Bachelor's - } \\
\text { number } \\
\text { of programs }\end{array}$ & $\begin{array}{c}\text { Master's - } \\
\text { number } \\
\text { of programs }\end{array}$ \\
\hline No Ethics & 0 & 3 & 2 \\
\hline Ethics included in 1 SSC & 1 & 9 & 8 \\
\hline Ethics in 1 IOC & 1 & - & 1 \\
\hline Ethics included in 2 SSCs & 2 & 3 & 5 \\
\hline Ethics in 2 IOCs & 2 & - & 2 \\
\hline Ethics in 1 SSC and 1 IOC & 2 & 1 & 3 \\
\hline Ethics in 1 SSC and 2 IOCs & 3 & - & 2 \\
\hline Ethics in 2 SSCs and 1 IOC & 3 & 5 & 8 \\
\hline Ethics in 1 SSC and 3 IOCs & 4 & - & 1 \\
\hline Ethics in 2 SSCs and 2 IOCs & 4 & 1 & 5 \\
\hline Ethics in 3 SSCs and 1 IOCs & 4 & - & 1 \\
\hline Total programs & & 22 & 38 \\
\hline & & \multicolumn{2}{|c}{ Source: Authors' own research. }
\end{tabular}

In order to judge the relative weight of courses teaching Ethics as stand-alone or comprising it as part of other topics we also used the number of credits allocated to each. Thus we found that at BSc level 33 out of 36 courses or $92 \%$ had 3 more credits or more out of the maximum of 6 . At Master's level the situation is similar with 74 out of 87 courses (or $85 \%$ ) being awarded 4 credits or more out of the maximum of 8 . We consider that this demonstrates that courses comprising Ethics are seen as having a relative importance as compared to other topics. A split between courses by number of credits awarded is illustrated below. 


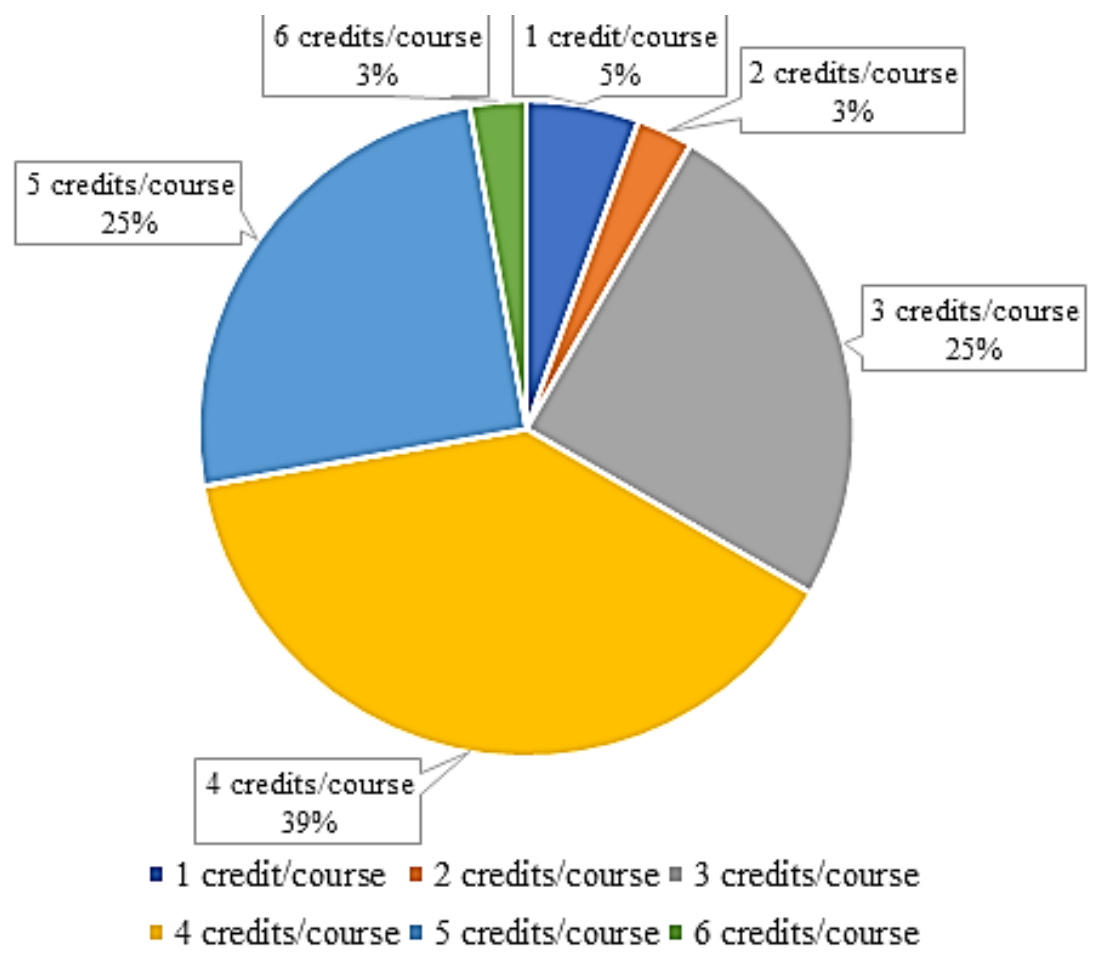

PICBE |

Figure 1. Ethics Courses in Analyzed Bachelor's degrees, split by Number of Allocated Credits

Source: Authors' own research.

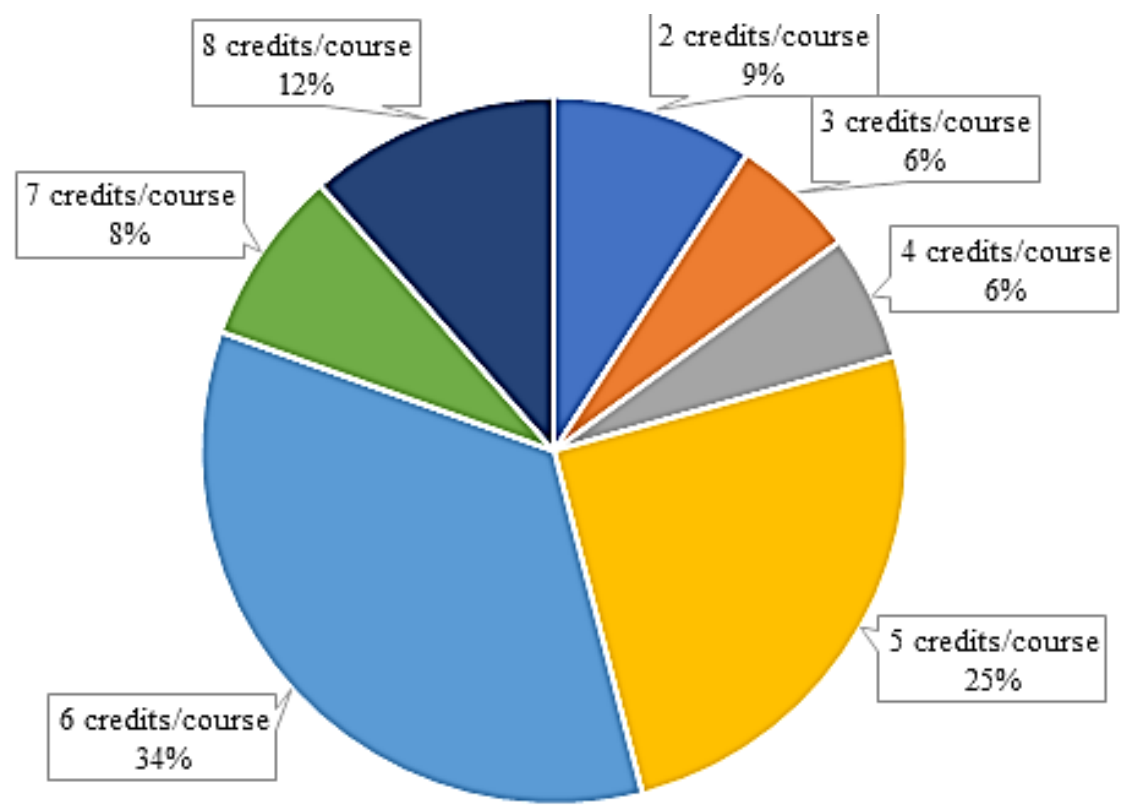

- 2 credits/course $=3$ credits/course $=4$ cre ditsicourse $=5$ credits/course

- 6 credits/course -7 credits/course -8 creditsicourse

Figure 2. Ethics Courses in Analyzed Master's degrees, split by Number of Allocated Credits

Source: Authors' own research.

DOI: 10.2478/picbe-2021-0066, pp. 705-714, ISSN 2558-9652 |

Proceedings of the $15^{\text {th }}$ International Conference on Business Excellence 2021 


\section{Conclusion}

Ethics education is as complex and versatile a subject as ethics itself and through this research we feel that we have just began to scratch the surface.

It is important to continue studying this field of ethics education (with all its variables) because it helps to further inform redesign of ethics curricula and interventions and gives a clearer demarcation of the effects that ethics educators (be them professors, mentors or whistleblowers) have on accounting professionals. Also, it might help the public to have clarity of what ethics training their professional accountant had, to further increase their confidence in the accountancy profession and business in general. Ethics is a vital subject for professional accountants and researching how it is taught from university level will provide some insight to educators and professional bodies regarding its relative importance and how courses are structured, allowing them to first of all map their course and then adjust their training and methods accordingly, to be in line or even exceed their peers.

As far as our research went, we could not find any other similar endeavor that aimed to determine how Ethics is taught in Romanian Economics faculties members of AFER in audit, accounting and BA, so this makes our research the first of its kind.

After an extensive work gathering and analyzing annual study plans of 60 economics faculties' programs in audit, accounting and BA, we were happy to note that Ethics is a subject featured in 55 of them, despite it not being formally required by the Romanian higher education regulator (ARACIS). Across these programs, we found 123 courses having ethics as main or secondary subject, $80 \%$ of which are mandatory. On average, each program had more than two courses comprising Ethics, with most of the Master's (some 50\%) including three or more courses in which ethics was tackled.

When analyzing number of credits awarded for courses approaching ethics, we could draw the conclusion that these are courses of relative importance some $85 \%$ of them having more than half of the maximum credits allowed for any subject.

Further research is needed, and we feel we haven't exhausted yet even the findings that could be drawn from the extensive data we gathered.

We could further analyze the difference between how (SSC, IOCs, optional, mandatory) and to what extent (number of courses, seniority of students) business administration, accounting and audit programs include Ethics in their courses as well as the difference between professional and academic ethics (as 22 of the 60 programs have a mandatory Academic Ethics program and 4 have it as optional). Also, we could see whether Ethics is taught more in junior or senior years depending on type of program.

What we could do to further detail our research is analyze all subject outlines of one program or more to further understand whether ethics is included in other courses which we might not have considered.

Also, we could carry out interviews with professors in order to have their take on teaching ethics and how it influences the future professional development of their students. 


\section{References}

ARACIS Romanian Agency to Ensure Quality in Higher Education (2017). Specific standards on external assesment of academic quality of Masters and BSc Programs.

Chelariu, A., Horomnea, E., Tanasă, F.E. (2014). Education Regarding Ethics in the Accounting Profession - A Literature Review. EIRP Proceedings, Vol 9.

Coate, C., and Mitschow, M. (2018). Luca Pacioli and the role of accounting and business: Early lessons in social responsibility. Research on Professional Responsibility and Ethics in Accounting, vol. 21, 1-16.

Davidson R.A. (2011). Ethics! Teaching Ethics to Accounting Students. Annual Summit on Business and Entrepreneurial Studies (ASBES 2011) Proceeding.

Fiolleau, K., Kaplan, S.E. (2017). Recognizing Ethical Issues: An Examination of Practicing Industry Accountants and Accounting Students. Journal of Business Ethics, 142, 259-276.

Fisher, D. G., Swanson, D. L., and Schmidt, J. J. (2007). Accounting Education Lags CPE Ethics Requirements: Implications for the Profession and a Call to Action, Accounting Education: An International Journal, 6(4), 345-363.

Fleming, A.I.M. (1996). Ethics and accounting education in the UK - a professional approach? Accounting Education, 5 (3), 207-217.

Huber, M., \& Mafi, S. (2013). Education par excellence: Developing personal competencies and character through philanthropybased education. Journal of Accounting Education, 31(3), September 2013, 310-332.

Jakubowski, S. T., Chao, P., Huh, S. K., Maheshwari, S. (2002). A cross-country comparison of the codes of professional conduct of certified / chartered accountants. Journal of Business Ethics, 35, 111-129.

Kaciuba, G. (2012). An instructional assignment for student engagement in auditing class: Student movies and the AICPA Core Competency Framework. Journal of Accounting Education, 30(2), June 2012, 248-266.

Kaufmann, L. (2018). Can Ethics be Taught? Journal for the Study of Religion, 31 (1), 207-223.

Kerr, D. S., and Smith, M. (1995). Importance of and approaches to incorporating ethics into the accounting classroom. Journal of Business Ethics, Vol. 14, 987-995.

Leung, P., Cooper, B., Dellaportas, S., Wong, G. (2008). Ethics Education for Accounting Students - a Toolkit Approach. Accounting Education: An International Journal, Special Issue on Teaching Resources in Accounting and Finance.

Limijaya, A. (2019). Accounting Ethics Education: What and How to Teach? Kajian Akuntansi, 21(2), Maret 2019.

Mathison, D. L. (1988). Business Ethics Cases and Decision Models: A Call for Relevancy in the Classroom, Journal of Business Ethics, 7, 777-782.

Miller, W., Becker, D., and Persteiner, A. (2014). The accounting ethics course reconsidered. Global Perspectives on Accounting Education, 11, 77-98

Miller, W.F., and Shawver, T.J. (2018). An Exploration of the State of Ethics in UK Accounting Education, Journal of Business Ethics, 153(4), 1109-1120.

Nguyen, L.A., Dellaportas, S. (2020). Accounting ethics education research: A historical review of the literature, University of Nottingham Ningbo China, made available under the terms of the Creative Commons.

Shawver, T.J., Miller, F.W. (2017). Moral Intensity Revisited: Measuring the Benefit of Accounting Ethics Interventions, Journal of Business Ethics 141, 587-603. 
Sinoi, E.A. (2021). "The impact of educated migrants and R\&D expenditures on innovation", Management \& Marketing. Challenges for the Knowledge Society, 16(1), 13-25. DOI: 10.2478/mmcks-2021-0002.

Spalding, Jr., A.D., Lawrie, G.R. (2019). A Critical Examination of the AICPA's New "Conceptual Framework" Ethics Protocol, Journal of Business Ethics, 155, 1135-1152.

Thorne, L. D., Ferrell, L., Montuori, L., and Willems, C. (1999). The Use of Behavioral Simulation to Teach Business Ethics, Teaching Business Ethics, 3(3), 283-294.

Young, J.J., Annisette, M. (2009). Cultivating imagination: Ethics, education and literature Critical Perspectives on Accounting, 20, 93-109. 